\title{
The Emergence of Black Literature and the Tragic Portrayal Black Women in the Slave Narratives
}

\author{
Dr. Prasanta Kumar Padhi \\ Department of English, Orissa Engineering College, India
}

\begin{abstract}
Slave narratives are known as the Black people's personal accounts of the terrible conditions of enslavement in the American Continent. Great part of these narratives was written in the form of autobiographies by African and AfrOican-American slaves. Through these written accounts the ex-slaves were able to condemn the enslavers and the system that legitimated their enslavement. Each ex-slave who wrote his or her story was also writing as a representative of those who were still captive and were not allowed to speak for themselves. These narratives were written within the institution of slavery. Slavery was to be shown as a perverted system that corrupted everyone who approached it or lived under it. In depicting the horrors of slavery, the narrators worked with the effects of the slave system both on the master's and on the slave's behavior. The portrayal of black women in these narratives, to a great extent, influenced American literature that was to come. As women, they had to face discrimination from the White and domestic oppression from the Afro-American men. In these narratives, those miseries have been depicted and they have been commonly defined in sexual terms either in literary or social grounds.
\end{abstract}

Keywords: dominant, Exploitation, humiliate, relationship, victimization

For black people in America, and for black literary authors, the slave narratives are a hallmark of identity. In spite of being strongly influenced by the standards of the white dominant society of the times, these narratives are the closest testimony black people have of the history and the literary creations of their ancestors. Although slave narratives established peculiar prototypal patterns in terms of structure and theme, they helped to present a reality that was not only an individual's experience but one that encompassed the experiences common to all kinds of slaves. The representation of black women in these narratives, to a great extent, influenced American literature that was to come and which would prove to be a dominating force in world literature. As Foster explains in her study about the victimization of black females in slave narratives, women have been commonly defined in sexual terms either in literary or social grounds. Frequently, the value and virtue of a woman has been measured by the manner in which she has used her capacity for reproduction. In literature, women have been represented in two major classes: "either far innocent princesses - objects to be protected from brutal lust and presented as treasures to one good man to have and to hold and to produce his offspring; or temptresses - sexually alluring but feared for their potential destructive power over men" (Foster, 1978, p.846).

The association of black women to sexuality is shown in slave narratives written both by black men and women. Olaudah Equiano, an African slave who worked for a slave trader, shows how African women were reduced to the level of sexual objects when he describes the behavior of the crew on his master's trading ship:

While I was thus employed by my master, I was often a witness to cruelties of every kind, which were exercised on my unhappy fellow slaves. I used frequently to have different cargoes of new Negroes in my care for sale; and it was almost a constant practice with our clerks, and other whites, to commit violent depredations on the chastity of the female slaves; ... (Equiano, p.74).

Equiano could not help the slave girls who were brought to the vessels and who had to submit to such cruelties. He adds, "I have known our mates commit these acts most shamefully, to the disgrace not of Christians only, but of men. I have even know them gratify their brutal passion with females not ten years old"(Equiano, p.74).

According to Foster, in their attempt to move the audience and change the status of the black slave woman, slave narrators included in their narratives many passages in which they retell the exploitation and the abuse imposed upon black women, either as workers, mothers, or females. As women were seen as fragile beings by the middle-class audience of the nineteenth century, it was difficult for that audience to understand how a woman could do a man's work in the fields. And, moreover, how could they survive in spite of the beatings, the sexual abuse, the physical and psychological tortures, and the mutilations they underwent? It is ironical, but as the slave narrators worked to show the exploitation and abuses suffered by black women in order 
to arouse feelings of compassion in their audiences, they also helped to create a negative attitude toward the black woman as woman and mother.

Because the depiction of black women in slave narratives shows strong women who managed to survive despite the sufferings and the sexual exploitation, a great prejudice against them was established. If a woman was not "pure", she was not worthy. Since black women could not maintain their chastity because the slave system forced them to act as sexual properties, Harriet Jacobs in Incidents in the Life of a Slave Girl, advocates that black women should not be judged by the same standards as other women (Jacobs, 1987, p.386). Because the majority of the masters had slave mistresses, the black woman ended being considered sexually attractive and a menace to the white woman. Jacob's narrative reveals the jealousy of her mistress, and how she was humiliated even while she avoided the impertinent base offers of her master. In her autobiography she reveals the status accorded to the black slave girls:

She will become prematurely knowing in evil things. Soon she will learn to trouble when she hears her master's footfall. She will be compelled to realize that she is no longer a child. If God has bestowed beauty upon her, it will prove her greatest curse. That which commands admiration in the white woman only hastens the degradation of the female slave. I know that some are too much brutalized by slavery to feel the humiliation of their position; but many slaves feel it most acutely, and shrink from the memory of it (Jacobs, p.361-362).

In the literature of the nineteenth century the black woman was often depicted as exotic, full of fire and sensuality in contrast to the white bourgeois woman, who was portrayed as delicate, pure, and fragile. Simultaneously, while society imposed upon black slaves moral notions of womanhood and motherhood such as purity, femininity, protection, maternal devotion and care, it denied the black women the right to develop familial relationships, especially in relation to love and care by separating husband from wife and mother from child. Biographical accounts of black family dismemberment are depicted in horrifying details in slave narratives, and many times the black woman was accused of not being a proper wife and a good mother for her own children, of being unable to fulfill the standards of womanhood and motherhood.

As Frances j. Foster argues, standards for motherhood were very rigid during the nineteenth century. According to these standards women should be sensitive and sentimental, truly subservient and faithful to their husbands whatever the circumstances, and more important, they must protect their children, making all the efforts to maintain the family united (Foster, p.850). Under such ideology, mothers should die rather than live without their children. Taking into account such criteria, a woman who could endure life being sexually exploited by her masters and seeing her husband and children been sold or ill-treated did not deserve the status of wife and mother. Therefore, from the point of view of the dominant white society of the nineteenth century, black women failed in the obedience to their husbands and in the nurturing and care of their own children.

However, the black woman's failure to adhere to the idealized image of motherhood of the nineteenthcentury American society was the consequence of slavery and not a question of ineptitude. Frederick Douglass' experience during childhood shows how slavery affected the development of the mother-child relationship. In his narrative, Douglass declares that he hardly saw his mother, and that almost no communication was established between them:

I never saw my mother, to know her as such more than four or five times in my life; and each of these times was very short in duration, and at night. She was hired by a Mr. Stewart, who lived about twelve miles from my home. She made her journeys to see me in the night, traveling the whole distance on foot, after the performance of her day's work (Gates, p.256).

Douglass does not recollect if he ever saw his mother in daylight time: "she was with me in the night. She would he down with me and get me to sleep, but long before I waked she was gone." Therefore, "very little communication ever took place between us. Death soon ended what little we could have while she lived, and with it her hardships and sufferings". Douglass was around seven years old when his mother died and "never having enjoyed, to any considerable extent, her soothing presence, her tender and watchful care, (he) received the tidings of her death with much the same emotions (he) should have probably felt at the death of a stranger." (Douglass, p.256). The fact that she walked a long distance on foot after a day of work shows her care, and her attempt, in spite of her condition, to develop an emotional link with her son. That they could not be together and she was a stranger to the little boy only attests the cruelty of the institution of slavery. 
Being set apart from their children, husbands, mothers, fathers, and any relatives they could have, the black women, as black people in general, had to develop mechanisms of self-protection. Otherwise, they would become mad. As Houston Baker points out, "in a world where men are property and women victims of the owner's lust, separation and a blunting or eradication of affection are normal" (Baker, p.40). The slaves' familial relationship, or better, the lack of it, was, therefore, the consequence of a system that employed contrastive and clashing notions of love and affection. For, if there were social, moral and affectionate attitudes that guided the relationship between white men and white women, these attitudes were not allowed to be shared by black people.

Black women were more than once abused in the name of the slave system, and this had a negative effect in the family structure of slaves. Adding to the fact that black women were not allowed to keep their children and take care of them, was the question of sexual abuse. In fact, sexual violence against female slaves was common among masters. Amidst the consequences of such treatment was the disruption of familial relationships. Slave narratives are full of examples in which wife, husband, and children are separated from each other. In the narrative of Henry Bibb we see the slave owners employed lashes and blackmails, using a black mother's love for her children, as means to obtain licentious pleasures. Bibb and his family were put in prison while they were waiting to be sold. Meanwhile, his wife and child were taken out of the cell and carried to another place. Bibb did not know the purpose and neither the place where they could be and thought that they were sold. Then one morning Bibb surprised, met his wife Malinda again in prison. There, he tells us:

\begin{abstract}
I had a short interview with my much abused wife, who told me the secret. She said that Garrison had taken her to a private house where he kept female slaves for the basest purpose. It was a resort for slave trading profligates and soul drivers, who were interested in the same business. Soon after she arrived at this place, Garrison gave her to understand what he brought her there for, and made a most disgraceful assault on her virtue, which she promptly repelled; and for which Garrison punished her with the lash, threatening her that if she did not submit that he would sell her child. The next day he made the same attempt, which she resisted, declaring that she would not submit to it; and again he tied her up and flogged her until her garments were stained with blood (Foster, p.847).
\end{abstract}

As Bibb's wife did not submit to her master's will even being flogged, Garrison changed his tactic and sent the child to another part of the city, saying to her that "he meant to sell it and that she should never see it again". Bibb and Malinda were again separated and years later Bibb found out that she "was living in a state of adultery with her master" (Foster, p.847).

For the slave owner it was a commodity to have sexual intercourse with black women and get them pregnant, for this was a means to enlarge their labor force without spending much money and to get profits selling slaves. The slave narrator in Narrative of Henry Box Brown gives a clear account of such practices and their consequences in the life of a slave:

It is my candid opinion that one of the strongest motives which operate upon the slaveholders, and induce them to retain their iron grasp upon the unfortunate slave, is because it gives them unlimited control in this respect over the female slave. The great part of slave holders are licentious men, and the most respectable and kindest of masters, keep some of their slaves as mistresses. It is for their pecuniary interest to do so in several respects. Their progeny is so many dollars and cents in their pockets, instead of being a bill of expense to them, as would be the case if their slaves were free; and mulatto slaves command a higher price than dark colored ones; but it is too horrid a subject to describe. Suffice is to say, that no slave has the least certainty of being able to retain his wife or husband a single hour; so that the slave is placed under strong inducements not to form a union of love, for he knows not how soon the chord wound around his heart would be snapped asunder, by the hand of the brutal slave-dealer (Foster, p.848).

Within the slave system, black human beings were seen as objects that would increase the profits of the white man. The term "objects' here is pertinent because this was the way black people, and black women in special, were viewed by white masters: objects that could be used and exchanged by the dominant part of society according to their needs and wishes. In the case of the black female slave narratives, and as a counterpart of the male narratives, the female narrators moved within a circumscribed space, within a neighborhood or a territory, with little adventure and almost no physical movement. Here we find, for example, Harriet Brent 
Jacob's Incidents in the Life of a Slave Girl. Jacob's narrative, or Linda Brent's, which is her real name, tells about her humiliations and seven years of confinement in her grandmother's garret in order to avoid her master's sexual exploitation. Although at the end she manages to escape and move to another city, it took a long time for this to happen. During seven years she remained in the same place, within a confined space, making plans for the escape of her children and herself.

Nevertheless, as Houston Baker points out in his study about discursive formations in AfricanAmerican Literature, although Brent's text to a major extent developed in "an essentially domestic arena in which the female slave will confront her destiny" she had to face "sudden transitions and violent disruptions"(Baker, p.50-51). The disrupting and transitory relationships between a slave mother and her children, all considered "transportable property", are well recorded in Brent's narration about the sorrows of New Year's Day, when the slaves were sold to new masters:

---to the slave mother New Year's Day comes laden with peculiar sorrows. She sits on her old cabin floor, watching the children who may all be torn from her the next morning; and often does she wish that she and they might die before the day dawns. She may be an ignorant creature, degraded by the system that has brutalized her from childhood; but she has a mother's instincts, and is capable of feeling a mother's agonies (Jacobs, p.350).

The link between mother and child is broken by what Baker terms "commercial deportation", a term that he sees as vital to the understanding of the "economics of slavery" and of the origins of Afro-American discourse. The term "economics of slavery" stands "as a governing statement in the Afro-American discourse", explains Baker, and signifies "the social system of the Old South that determined what, how and for whom goods were produced to satisfy human wants." Moreover, the economy of the South was based on an "exploitative mode of production embodied in the plantation system and spirited by a myth of aristocratic patriarchalism" (Baker, p.26-27). In terms of economic production, the labor produced by slaves was exploited as a means to obtain and increase the master's profit. Economic patriarchalism signified, according to Baker, "the master as the owner of all stock in his 'children-as-slaves."' (Baker, p.27) Taking into account the economics of slavery, female slave narratives such as Harriet Jacob's seem to emphasize that the value of a female slave is not placed on the works of her hands, as it is for the male slave. Instead, as Baker explains, the narrative calls attention to the fact that pregnancy in black women was seen as profitable business to white masters. In such context, "women are considered of no value unless they continually increase their owner's stock. They are put on a par with animals" (Baker, p.51). The mulatto children that were born as a result of white men's violation of black women were, for their masters, an increase in stock and also a sign of domination over women's capability for reproduction.

Linda Brent was able to change her status as a black woman and managed to get her children and herself free. In fact, Linda's children were born from a white man, but she, in a manner which proves her determination, had had an affectionate involvement with a man of her own choice, and not with her own master. This proves that she did not allow her master to use her body as a way to increase his commercial stock. Moreover, she managed to avoid domination over her body and spirit. Nevertheless, cases such as this were extremely rare during slavery and, as slave narrators used the victimization of black women to show the extremes to which the white men's hunger for domination could go, the image of the black female became frequently associated with illicit sexual intercourse, physical mutilation and incapacity for mothering. Foster mentions how in some male slave narratives the authors explored "their audience's attitudes toward the proper treatment of women when they emphasized the lack of special consideration even for nursing mothers and pregnant women." To document her point she quoted a passage from the Narrative of the Life of Moses Grandy, which is transcribed here:

On the state I am speaking of, those women who had sucking children suffered much from their breasts becoming full of milk, the infants being left at home; they therefore could not keep up with the other hands. I have seen the overseer beat them with raw hide, so that blood and milk flew mingled from their breasts. A woman who gives offence in the field, and is large in the family way, is compelled to lie down over a hole made to receive her corpulency, and is flogged with the whip, or beat with a paddle, which has holes in it; at every hole comes a blister. One of my sisters was so severely punished in this way, that labor was brought on, and the child was born in the field (Foster, p.851). 
Perhaps male authors were not aware of the effect their depiction could have upon the social attitudes toward "black women as women", argues Foster. However, she notices that female narrators knew "very well the status accorded women who deviated from the norm". Although these women did not question the role definitions for women, they tried to excuse their actions. Jacob's narrative, for example, emphasized how she fought against the base proposals of her master and said that the slave women should not be judged by the same standards of other women because theirs is a peculiar situation.

The consequences of the depiction of black women in slave narratives ended up being negative, argues Foster. Although the slave authors' discussion of the "particular abuses of slave women contributed greatly to their cause since it appealed to the American protective attitudes toward women at a basic level", it also portrayed slave women as "ravished females and inept mothers". (Foster, p. 852). What the male slave narratives seem to portray and really want to accomplish is to show that slavery and the white people who connived with that institution degraded the virtue of black women and did not allow them to fulfill the most basic needs of human beings, those of being able to love and be loved, to nurture and be nurtured, to develop emotional and affectionate ties, and to have familial relationships.

Since the white, middle-class concepts of femininity in the nineteenth century did not allow inclusion of beings able to survive the disintegration of familial ties, sexual degradation, and physical pain, black women were posed outside the boundaries of female sensibility: "as victim, the black woman became suspect since her submission to repeated violations was not in accord with prevailing notions of that femininity which caused women to die rather than to suffer abuse" (Foster, p.853).

Before the Civil War the American society began to spread what was termed as "The Cult of True Womanhood", which was focused on the stereotype of the perfect, loving "Angel of the Earth"- The Mother. This status given to motherhood was "in all of its particulars, fraudulent-cruelly hypocritical toward the white women and barbarous towards blacks." (Wolff, p.107).

Wolff claims that this stereotype was harmful both to white and black women because, throughout the nineteenth century, mothers had no legal rights, what is to say no real power, on the decisions that concerned their children. Married white women "had no legal claim" to the children they bore. The father was the chief guardian, the withholder of power. Therefore, in spite of the national reverence to motherhood (in this case, an idealized image of the mother), "actual mothers had no real power to protect the babies they had borne" and the moral responsibility that was given to them had to be combined with "de facto impotence". (Wolff, p107).

The situation was much worse for the black slave women. If they were married, neither they nor their husbands could keep the children because none had legal claims to them. Even if the black women happened to be married to white men, their children could not be free because it was legally stated that a child born of a black slave should follow the status of the mother and, as so, belonged to her master. There was no law protection for slaves and the masters could use them at their will, even if it was the most perverse. The apology for "The Angel of the Earth" could not be applied to African American women, advocated the enslavers, because "their nature was more primitive and less refined than that of white women; they were not 'civilized' not really 'attached' to their children." (Wolff, p.107).

In literature, "The Cult of True Womanhood" was spread in accordance with the sentimental novel of the eighteenth and nineteenth century. Broadly, the sentimental novel exploited tenderness, compassion or sympathy to a disproportionate degree by presenting an idealized view of its subject. Pamela, a novel by the English writer Samuel Richardson, is a good example of this kind of literature. Published in 1740, this novel tells the story of a servant who avoided the seduction of her mistress' son and was rewarded by marriage. She was portrayed as a tender and loving woman, completely attached to her moral beliefs, in such a way that the clergymen thought she was the perfect model of a woman, thus the novel came to be recommended for the education of the women's heart. Later on this image was carried to the representation of motherhood, thus creating the image of the idealized Madonna, which guided the American literary imagination and its habits of mind in the mid-nineteenth century.

The images of femininity presented throughout the nineteenth century were more a matter of a dominant discourse than a presumable "reality". If we take Incidents in the Life of a Slave Girl into consideration we realize that the women's chastity and virtue advocated by the white man's discourse clashed with the reality imposed to the slave woman, who was obliged to submit. For the slave woman, the relationship with the white man, most of the time, meant rape. As Baker argues, "submission to the master's will becomes the only act of value the slave woman can perform in a violent patriarch" (Baker, p.53). Those who avoided submission had to pay a high price, others tried to negotiate with the economics of slavery, such as Linda Brent. The negotiation nevertheless obliged her to spend part of her life in confinement. 


\section{References}

[1]. Baker, Houston. "Figurations for a New American Literary History: Archaeology, ideology, and Afro-American Discourse. In Blues, Ideology, and Afro-American Literature: A Vernacular Theory. Chicago: University of Chicago Press, 1985, p.15-63.

[2]. Douglass. Frederick. Narrative of the Life of Frederick Douglass. In Gates Jr., Henry7 Louis (Ed.). Classic Slave Narratives. New York: Penguin Books, 1987.

[3]. Emecheta, Buchi. The Slave girl. London: Allison and Busby, 1977.

[4]. Equiano, Olaudah. The Life of Ouladah Equiano. In Gates Jr., Henry Louis (Ed.).Classic Slave Narratives. New York: Penguin Books, 1987.

[5]. Foster, Frances J. "Ultimate Victims: Black Women in Slave Narratives". Journal of American Culture, v. I, n.4, p. 845-854, 1978.

[6]. Gates Jr., Henry Louis and Mckay, Nellie Y. Eds. The Norton Anthology of African American Literature. New York and London: Norton, 1977.

[7]. Hedin, Raimond. "The American Slave Narrative: The Justification of the Picaro". American Literature, v. 53, n.4, 1982.

[8]. Jacobs, Harnet Brent, Incidents in the Life of a Slave Girl. In Gates Jr., Henry Louis (Ed.). Classic Slave Narratives. New York: Penguin Books, 1987.

[9]. Kelley, Robin D. G., and Earl Lewis, eds. To Make Our World Anew: A History of African Americans. New York: Oxford University Press, 2000.

[10]. Wolff, Cynthia Grifiin. "Margareth Garner: A Cincinnati Story" In Lohmann, Christoph (Ed.). Discovering Difference: Contemporary Essays in American Culture. USA: Indiana University Press, 1993. p.105-122.

[11]. Weld, Theodore Dwight. Slavery As It Is. Boston press, 1839. 